DOI:https://doi.org/10.37699/2308-7005.5-6.2019.20

M. Yu. Syzyi

State Institution $« V . T$. Zaitsev

Institute of General and

Emergency Surgery of NAMS

of Ukraine», Kharkiv

(C) Syzyi M. Yu.

\section{URGICAL TACTICS IN WOUNDS OF PHARYNX AND CERVICAL ESOPHAGUS}

Summary. The results of surgical treatment of 98 patients with penetrating injuries to the pharynx and cervical esophagus are presented. The patients were divided into the main and the comparison group. In the comparison group, the traditional principles of intervention were used. In the main group, surgical intervention was performed with a mini access on the neck 3-4 cm in length using a ring-shaped retractor. In the main group there was a twofold decrease in the frequency of purulent complications after surgical treatment of penetrating injuries to the pharynx and cervical esophagus, in comparison with the comparison group.

Key words: neck, wound, pharynx, cervical esophagus.

\section{Introduction}

Penetrating injuries to the pharynx, esophagus and large blood vessels take a leading position in the structure of the neck wounds, wherein more than $50 \%$ of perforations occur in the cervical esophagus $[1,4,7]$. Injuries to the esophagus with external neck wounds in $64-73 \%$ of patients are combined nature $[2,5,9]$. «Vivid» symptoms of injuries to large blood vessels and respiratory tract mask injuries to the pharynx and esophagus, which complicate the timely diagnosis of the injury. The correct diagnosis is established only after the onset of purulent complications that develop in $28-78 \%$ of patients with perforation of the cervical esophagus $[6,8]$. Late diagnosis of injury to the pharynx and cervical esophagus significantly worsens treatment outcomes. When revealing perforation of the esophagus in the first day after injury, the mortality is $8-9 \%$, and at a later diagnosis - 25-53\% [5]. If perforation of the esophagus was diagnosed later than two days after the injury, the mortality is approaching $100 \%[3,10]$. There is high mortality in perforations of the pharynx and esophagus (9.6-55.0\%) primarily due to the development of purulent complications [2]. In case of injury to the cervical esophagus possible development of periesophagitis [2, 9], deep neck phlegmon [6], secondary mediastinitis [4], pleurisy and pleural empyema [1], esophagus-pleural [8], esophagus-tracheal [9] and esophagus-aortic fistulas [7], osteomyelitis of the cervical vertebrae and purulent meningitis [3]. Constant passing of highly contagious contents of the esophagus (saliva, food, air) supports and complicates the course of the destructive-inflammatory process around the esophageal fiber [6]. At a late (more than $24 \mathrm{~h}$ ) detection of perforation of the cervical esophagus, the survival rate is reduced to $60 \%$ and is not particularly de-pendent on the type of treatment [5].

\section{Materials and methods}

The study group consisted of 98 patients with penetrating injuries to the pharynx and cervical esophagus that underwent surgical treatment. Surgical interventions for perforations of the pharynx and cervical esophagus were performed under general anesthesia (endotracheal anesthesia). Patients with esophageal wounds were hospitalized in the hospital department and had different approaches to treatment of penetrating injuries to the pharynx and cervical esophagus, resulting in an analysis of the two groups of victims. In the comparison group, the traditional principles of intervention were used. Operative access was the classic colotomy. Suture of the defect of the pharynx and cervical esophagus were produced only during the first 6 hours from the moment of injury and in the absence of visible inflammatory tissue changes. There was applied normal nodal sutures, only passive drainage of the wound was used, and if the purulent complications were presented, gastrostomy was formed in order to exclude the esophagus from the passage of food.

In the main group, surgical intervention was performed with a mini access on the neck $3-4 \mathrm{~cm}$ in length using a ring-shaped retractor. The defect of the pharynx and cervical esophagus was sutured in all cases, regardless of the time of injury and the nature of inflammatory tissue changes. Two-row knot sutures were applied. In the presence of technical capability, the sutures were applied in the trans-verse direction. The location of injury was strengthened by local muscle tissue. Only active aspiration drainage was used, and the shutdown of the esophagus from the food passage was carried out by installing the probe. In the main group $(\mathrm{n}=56)$ and in the comparison group $(\mathrm{n}=42)$, more often - $54(55.1 \%)$ cases had damage to the left wall of the pharynx and cervical esophagus, less often to the right wall - 36 $(36.8 \%)$, the anterior wall of the esophagus was traumatized in 7 (7.1\%) patients.

The combination of injuries to the cervical esophagus and major blood vessels, larynx, trachea worsened the condition of the patients and masked the clinical picture of wound of the esophagus it-self.

The most commonly symptoms of perforation of the pharynx and cervical esophagus are dysphagia and painful swallowing - 44 (44.9\%), pain in the neck region - $34(44.7 \%)$, hemoptysis - 
20 (20.4\%), food, saliva - 16 (16.3\%), hoarseness - $16(16.3 \%)$, subcutaneous emphysema $18(18.4 \%)$, air discharge from a wound, it was local manifestations of perforation of the esophagus. For external injuries of cervical esophagus - swelling, hyperemia, neck infiltration was observed in 6 (6.1\%) cases, and fever, as a manifestation of general intoxication, was observed in only $10(10.2 \%)$ patients. This contributed to the early diagnosis of the esophagus perforation in most patients: $85.7 \%$ of penetrating wounds were detected during the first 6 hours.

\section{Results and discussion}

In the main group of patients with perforation of the pharynx and cervical esophagus used retractor mini-colotomy in $54(96.4 \%)$ patients and longitudinal colotomy according to Razumovsky - in 26 $(61.9 \%)$ patients in the comparison group.

In 10 patients in the main group and in 4 patients in the comparison group, two-way longitudinal colotomy was per-formed to facilitate the inspection of the neck wounds.

In $2(3.6 \%)$ patients in the main group and in $16(38.1 \%)$ in the comparison group - only neck wounds that were al-ready present were enlarged to the desired size for the inspection. In the main group, longitudinal colotomy was not performed for only 2 patients with a transverse inter-section of the esophagus.

Features of surgical intervention with mini access consist in the need for addi-tional specialized tools and lighting. Ad-ditional tools: necessary special miniature dissector for tissue dissection, vascular clamps curved at an angle, and needle holders bent in the plane, which allows the stitching of tissue in the depth of the wound, while not restricting the field of view of the surgeon. The combined injuries to the pharynx and cervical esophagus with other internal organs were $75.0 \%$ in the main group and $71.4 \%$ in the comparison group.

Ligation of the damaged blood vessels was performed the most often - in 16 patients in the main group and in 14 patients in the comparison group. The vascular sutures of the injured major blood vessel were performed in 6 patients in the main group.

Tracheostomy was formed in 12 patients in the comparison group and $6-$ in the main group. The drainage of the pleural cavity was performed in 4 patients in each group. Diagnostic laparoscopy was performed in 2 patients with combined blunt stomach injury in the main group, no injuries to the internal organs of the abdominal cavity was detected. In case of in-juries to the esophagus, the suturing of the perforation wall defect and the formation of the esophagostomy were performed.

In the comparison group, the suturing of the perforation defect of the pharyngeal wall and cervical esophagus were performed only in the early time after the wound (up to 6h), in the absence of purulentinflammatory events in the sur-rounding tissues.

In the main group, the defect of the pharyngeal wall and esophagus has al-ways been sutured, regardless of the time that passed after the injury, and condition of the surrounding tissues. In this case, a ring-shaped retractor for mini-colotomy was used, two rows of sutures and the sutures line of the esophagus was strengthened by the cluster of surrounding tissues. Primary resection of the perforated esophagus in patients with neck injuries was not performed. In $56(100 \%)$ patients in the main group and in 24 (57.1\%) patients in the comparison group, suturing of the wall defect of the pharynx and esophagus was performed. In the main group in $6(10.7 \%)$ cases after the injury was more than 6 hours passed, in $2(3.6 \%)$ - more than 24 hours passed.

In $18(42.9 \%)$ cases in the comparison group, the defect of the pharynx and esophagus was not sutured at the late (more than 6 hours) detection of esophageal injury (6 patients) and with expressed inflammatory changes in the surrounding tissues (12 patients). So, there was implemented draining of the damaged area and formed esophagostomy.

Drainage of wound of the neck as one of the key moments of the operation for perforation of the cervical esophagus paid special attention. In the main group, the retractor mini-colotomy for perforation of the cervical esophagus was completed by active aspiration drainage. The drain-age tube was brought to the site of the injury of the esophagus and led to the skin through a contrapertura.

In the comparison group, in case of damage to the esophagus, passive drain-age was performed using polyvinylchloride tubes, gloves-outlets and their combination with swabs.

In the comparison group, passive drainage with polyvinylchloride tubes was widely used - 12 $(28.6 \%)$, flat latex outlet $-6(14.3 \%)$, a combination of tubular drainages with tampons - $22(52.4 \%)$. Wound drainage with swabs was per-formed only in $2(4.7 \%)$ patients with external penetrating wounds of the cervical esophagus in the comparison group. The swab swelled very quickly and became an obstacle to the outflow, so in the future drainage of wound of the neck with swabs was not fulfilled.

To exclude an injured esophagus from a passage of food, two methods were used: the establishment of a constant nasogastric probe or the formation of gastrostomy. To create functional rest of the esophagus, all 56 patients in the main group and 14 patients $(67.7 \%)$ in the comparison group with the perforation of the cervical esophagus were installed nasogastric probe. Gastrostomy by common techniques was formed in $14(33.3 \%)$ patients in the comparison group to exclude the damaged esophagus from the food passage.

As a result of surgical treatment of penetrating injuries of the pharynx and cervical esophagus in the 
main and the comparison group, the following results were obtained.

In the main group complications after surgical treatment occurred in $14(25.0 \%)$ patients, and in the comparison group - in $22(52.4 \%)$. The analysis of the complications of penetrating injuries of the pharynx and cervical esophagus shows that in the comparison group, postoperative wound purulence $(42.9 \%)$ and neck abscess $(14.3 \%)$ were significantly more frequent than in the main group (in the main group $-14.3 \%$ and $3.6 \%$ respectively). The rate of development of acute mediastinitis in the comparison group was $9.5 \%$, and in the main group - $6 \%$; lung abscess $-4.8 \%$ and $7.1 \%$ respectively, but these differences were not statistically significant. In addition, in the comparison group, there were purulent complications such as pleural empyema $(9.5 \%)$ and thrombosis a. carotis interna with ischemic stroke (4.8\%), which were not registered in the main group.

In each group, the failure of sutures of the pharynx developed in 2 patients. In both cases, the suturing of the defect of the pharyngeal wall was performed in the early period after injury (after 3 and 4 hours).

It was established that using the technique of mini-access for treatment of in-juries of the cervical esophagus in the main group did not increase the frequency of development failure of the esophageal sutures and amounted to $3.6 \%$ (in the comparison group - $8.3 \%$ ). At the same time, the sutures on the injured esophagus in the main group were applied with signs of inflammation in $39.3 \%$ of patients. This confirms the expediency of suturing the defect of the pharynx and cervical esophagus using the proposed methodology.

It should be noted that even in the development of failure of sutures of the pharynx or esophagus in two cases man-aged to achieve convalescence of patients without repeated interventions. Esophageal-aortic fistulas in the studied groups of patients were not registered.

\section{Conclusions}

Complications in both groups were noted in $36 \mathrm{pa}-$ tients $(36.7 \%)$ : 14 (25.0\%) patients in the main group and $22(52.4 \%)$ in the comparison group. In total there were 42 complications ( 38 - purulent nature) in the comparison group and 22 complications (20 - purulent nature) in the main group. In the main group, using the proposed surgical tactics contributed to a twofold decrease in the frequency of purulent complications after surgical treatment of penetrating damages of the pharynx and cervical esophagus, compared to the group where the treatment was performed according to traditional methods.

\section{REFERENCES}

1. Абакумов М. М. Двадцатилетний опыт диагностики и лечения при различных формах гнойного медиастинита / М. М. Абакумов, А. И. Погодина, Т. Г. Бармина, М. В. Снегирев //Вестн. хирургии им. И. И. Грекова. - 2001. -№ 1. - C. 80-85.

2. Гатауллин Н. Г. Инородные тела и повреждения пищевода / Н. Г. Гатауллин и др. // Новые технологии в хирургии: труды международного конгресса. -Ростов-на-Дону, 2005. - 158-159.

3. Доскалиев Ж. А. Миниторакотомия с эндовидеоподдержкой при заболеваниях органов грудной клетки / Ж. А. Доскалиев, А. И. Колос, О. Б. Оспанов и др. // Эндоскопическая хирургия. - 2005. - № 1 . - С. 43.

4. Кузнецов Я.О. Совершенствование методов лечения гнойных раневых поверхностей /Я.О.Кузнецов, Г.Я. Хулуп // Новости хирургии. -2009.-Т. 17.-№1.- С. 55-61.

5. Мирошников Б. И. Повреждения пищевода / Б. И. Мирошников, Г. А. Белый // Вестн. хирургии им. И. И. Грекова. - 1998. - № 6.-С. 68-71.
6. Погодина А. Н. Клиника, диагностика и лечение повреждений пищевода и их последствий: Автореф. дис. д-ра мед. паук / А. П. Погодина. - М., 1989. - 35 с.

7. Hinojar A. G. Management of hypopharyngeal and cervical oesophageal perforations / A. G. Hinojar, M. A. Diaz Diaz, Y. W. Pun, A. A. Hinojar // Auris. Nasus. Larynx. - 2003. -Vol. 30. - â,,-2. - P. 175-182.

8. Jougon J. Esophageal perforation: life threatening complication of endotracheal intubation / J. Jougon, O. Cantini, F. Delcambre et al. // Eur. J. Cardiothorac. Surg. - 2001. - Vol. 20. - № 1. - P. 7-10.

9. Katsetos M.C., Tagbo A.C., Lindberg, Rosson R.S. Esophageal perforation and mediastinitis from fish bone ingestion / M. C Katsetos, A. C Tagbo, M. P. Lindberg, R. S. Rosson // South. Med. J. - 2003. -Vol.96. -№5. -P. 516-520.

10.Pompili A., Canitano S., Caroli F., Caterino M., Crecco M, Raus L., Occhipinti E. Asymptomatic esophageal perforation caused by late screw migration after anterior cervical plating: report of a case and review of relevant literature / A. Pompili, S. Canitano, F. Caroli // Spine. - 2002. -Vol. 27. - № 23. - P. 499-502. 
ХІРУРГІЧНА ТАКТИКА ПРИ ПОРАНЕНІ ГЛОТКИ ТА ШИЧНОЇ ЧАСТИНИ СТРАВОХОДУ

\section{М. Ю. Сизий}

ХИРУРГИЧЕСКАЯ

ТАКТИКА ПРИ РАНЕНИИ ГЛОТКИ И ШЕЙНОЙ ЧАСТИ ПИЩЕВОДА

\section{М. Ю. Сизий}

Резюме. Представлені результати хірургічного лікування 98 пацієнтів з проникаючими ушкодженнями глотки і стравоходу. Пацієнти були розділені на основну та групу порівняння. У групі порівняння використовувалися традиційні принципи втручання. В основній групі хірургічне втручання проводилося за допомогою міні-доступу на шиї довжиною 3-4 см з використанням кільцевого ретрактора. В основній групі спостерігалося двократне зниження частоти гнійних ускладнень після хірургічного лікування проникаючих ушкоджень глотки і шийної частини стравоходу в порівнянні з групою порівняння.

Ключові слова: шия, рана, глотка, шийний відділ стравоходу.

Резюме. Представлены результаты хирургического лечения 98 пациентов с проникающими повреждениями глотки и пищевода. Пациенты были разделены на основную и группу сравнения. В группе сравнения использовались традиционные принципы вмешательства. В основной группе хирургическое вмешательство проводилось с помощью мини-доступа на шее длиной 3-4 см с использованием кольцевого ретрактора. В основной группе наблюдалось двукратное снижение частоты гнойных осложнений после хирургического лечения проникающих повреждений глотки и шейной части пищевода по сравнению с группой сравнения.

Ключевые слова: шея, рана, глотка, шейный отдел пищевода. 